\title{
Soil structure degradation in patches of alfalfa fields
}

\author{
María Celeste Miretti ${ }^{1}$; Silvia Imhoff ${ }^{1 *}$; Alvaro Pires da Silva ${ }^{2}$; Raúl Lavado ${ }^{3}$ \\ ${ }^{1}$ UNL/FCA/CONICET - Depto. Ciencias del Ambiente, Kreder 2805 - S3080HOF - Esperanza, Argentina. \\ ${ }^{2}$ USP/ESALQ - Depto. Ciência do Solo, C.P. 9 - 13418-900 - Piracicaba, SP - Brasil. \\ ${ }^{3} U B A / F A / C O N I C E T$ - Depto. Ing. Agrícola y Uso de la Tierra, Av. San Martín 4453 - C1417DSE - Buenos \\ Aires, Argentina. \\ *Corresponding author <simboff@fca.unl.edu.ar>
}

ABSTRACT: Alfalfa (Medicago sativa) is the basic forage resource for milk production in the flat Pampa of the Santa Fe Province of Argentina. However, the presence of microrelief with patches threatens the expansion of the area cultivated with alfalfa. The lower productivity in the patches is attributed to the inferior soil physical quality. The objectives of this study were to quantify indicators of soil physical quality and to establish the soil properties that would affect the alfalfa productivity in patches (PA) and normal areas (NA). Additionally, the macro and micro nutrient contents in both areas were determined. The experiment was carried out on an Aquic Argiudoll. Eighteen sampling sites, nine in NA and nine in PA were established. At each site, undisturbed soil samples $(5 \times 5 \mathrm{~cm}$ cores) were collected to measure soil bulk density $(\mathrm{Bd})$, soil resistance to root penetration $(\mathrm{PR})$, effective stress $(\sigma)$, the water release curve and the least limiting water range (LLWR). Disturbed soil samples were also taken to determine macro and micronutrient contents, and particle size distribution. Non differences were detected for soil chemical properties between PA and NA. Aggregate size distribution indicated predominance of small aggregates in PA. Bd, PR and s were higher in PA than in NA, while the LLWR was narrower. Inadequate aeration under conditions of excessive soil moisture and inappropriate soil mechanical resistance when the soil is dry would affect alfalfa productivity. The overall results indicate that the soil physical quality in PA is lower than in NA.

Key words: soil physical properties, soil nutrient content, alfalfa growth

\section{Degradação da estrutura do solo em "patches" em pastagens de alfafa}

\begin{abstract}
RESUMO: A alfafa (Medicago sativa) é a pastagem básica na produção de leite na Pampa plana da Província de Santa Fe da Argentina. Entretanto, a presença de microrelevo com "patches" (áreas de menor produção) ameaça a expansão da cultura. A menor produtividade nos "patches” foi atribuída â inferior qualidade física do solo. Avaliaram-se indicadores de qualidade física do solo e estabeleceram-se as propriedades do solo que podem afetar a produtividade da alfafa nos patches (PA) e nas áreas normais (NA). Adicionalmente, os conteúdos de macro e micronutrientes foram determinados nas duas áreas. $O$ experimento foi conduzido numa fazenda com solo Argiudol áquico. Dezoito pontos de amostragem foram estabelecidos, nove em PA e nove em NA. Em cada ponto foram coletadas amostras não perturbadas $(5 \times 5 \mathrm{~cm})$ para a determinação da densidade do solo $(\mathrm{Ds})$, resistência do solo à penetração das raízes $(\mathrm{RP})$, estresse efetivo $(\sigma)$, curva de retenção de água e intervalo hídrico ótimo (IHO). Amostras perturbadas foram coletadas para avaliar o conteúdo de macro e micronutrientes, e a distribuição de partículas por tamanho. Não foram encontradas diferenças nas propriedades químicas entre PA e NA. Existe predomínio de agregados pequenos em PA, e a Ds, RP e s atingiram valores mais elevados em PA, enquanto o IHO foi mais estreito. Inadequada aeração em condições de excessiva umidade do solo e elevada resistência mecânica em condições de secamento poderão afetar a produtividade da alfafa. Os resultados indicam que a qualidade física do solo em PA é inferior que em NA.

Palavras-chave: propriedades físicas do solo, conteúdo de nutrientes, crescimento de alfafa
\end{abstract}

\section{Introduction}

Milk production in the flat Pampa of Santa Fe Province, Argentina, is characterized by the permanence of animals at the fields and the by use of a short-duration grazing system with alfalfa (Medicago sativa) due to its high dry matter yield and good nutritional quality (Comeron and Romero, 2007; Juan et al., 1995). Nonetheless, the presence of sectors with lower plant development in the fields threatens the expansion of the cultivated areas with alfalfa. These sectors are known as "patches" and are associated to other sectors consid- ered "normal", where alfalfa presents much better growth.

Patches are characterized by their relatively well defined boundaries; they can occupy from 10 to $50 \%$ of the total surface, reinforcing their relevance (Bonadeo et al., 2006). So far, no agreement has been reached about the reasons that originate differences in pasture productivity. Some researchers have associated patches with management issues, presence of salt and sodium and depressed microrelief (Bonadeo et al., 2006; Panigatti et al., 1971; Romero et al., 2000). Another possibility may be related to soil structure degradation inr the patches. 
Soil degradation is a common process especially in flat areas where soils are intensively cultivated or grazed (Hamza and Anderson, 2005; Harrison et al., 1994; Mapfumo et al., 1998; Taboada et al., 1998a; Taboada et al., 1999). Degradation was associated with changes in soil bulk density, aggregate size distribution, soil resistance to root penetration, water and oxygen availability, and as a consequence, appears the decrease in crop productivity (Masle, 1998; Masle and Passioura, 1987; Passioura, 1988; Veen and Boone, 1990).

The hypothesis underlying this investigation is that soil conditions in patches is more restrictive for alfalfa growth than in normal areas, which determines the lower productivity even when similar chemical conditions exist in both areas. Therefore, the objectives of this study were to: i) quantify indicators of soil physical quality in patches and normal areas of an alfalfa pasture; ii) determine macro and micro nutrient contents; iii) establish which soil properties would affect alfalfa productivity in both areas.

\section{Material and Methods}

The experiment was carried out in a plot cultivated with alfalfa, located in Humboldt ( $31^{\circ} 42^{\prime} \mathrm{S}$; 61 $\left.61^{\circ} 03^{\prime} \mathrm{W}\right)$, Province of Santa Fe (Argentina). The climate of the region is mesothermic subhumid-humid (C2B'3ra') according to the Thornthwaite classification (Mosconi et al., 1981), with annual isohyets varying from 800 to $1000 \mathrm{~mm}$. The landscape is predominantly flat with small depressed microrelief (from 4 to $8 \mathrm{~m}$ in diameter). The soil is from the Humboltd series, an Aquic Argiudoll, with $70 \mathrm{~g} \mathrm{~kg}^{-1}$ sand, $700 \mathrm{~g} \mathrm{~kg}^{-1}$ silt, and $230 \mathrm{~g} \mathrm{~kg}^{-1}$ clay.

Eighteen sites were selected and sampled, nine in "normal" areas (NA) and nine in "patches" (PA), which were mainly located in depressed microreliefs. In each site composite disturbed samples were collected at 0 10 and $10-20 \mathrm{~cm}$ depths. Samples were air-dried and passed through a $2.0 \mathrm{~mm}$ sieve for analyses. The following determinations were made: $\mathrm{pH}\left(\right.$ in $\left.\mathrm{Cl}_{2} \mathrm{Ca} 0.01 \mathrm{M}\right)$, particle size distribution, organic matter (OM) (through oxidation with a potassium dichromate solution), extractable phosphorous $(\mathrm{P})$, exchangeable potassium $\left(\mathrm{K}^{+}\right)$, calcium $\left(\mathrm{Ca}^{2+}\right)$, magnesium $\left(\mathrm{Mg}^{2+}\right)$, aluminium $\left(\mathrm{Al}^{+3}\right)$, $\mathrm{H}^{+}+\mathrm{AL}^{+3}$ (extracted through ion exchange resin), sulphur expressed as sulphate $\left(\mathrm{S}_{-} \mathrm{SO}_{4}{ }^{2-}\right)$ (turbidimetric determination), boron (B), copper (Cu), zinc ( $\mathrm{Zn})$, manganese $(\mathrm{Mn})$, iron $(\mathrm{Fe})$ determined as described by van Raij (1998).

Soil samples were taken with a trowel shovel to determine dry aggregate size distribution (Perfect et al., 2002). Samples $(1,000 \mathrm{~g})$ were air-dried for $36 \mathrm{~h}$ and allowed to fall from a $3 \mathrm{~m}$ height to simulate tilling. Next, they were passed through a $16 \mathrm{~mm}$ mesh sieve to separate larger size material, which was discarded. Each sample, made up of aggregates smaller than $16 \mathrm{~mm}$, was placed on a nest of flat sieves (sized 11.1; 7.93; 6.35; 4; 2; 1 and $0.5 \mathrm{~mm}$ ) and shaken for $1 \mathrm{~min}$ in order to obtain aggregate mechanical separation. The material retained in each sieve was weighed and its mass was corrected for soil mass dried in an oven at $105^{\circ} \mathrm{C}$. Aggregate size distribution was determined from these data and the geometric mean diameter (GMD) was calculated according to the methodology described by White (1993):

$\mathrm{GMD}=\sum_{\mathrm{i}=1}^{\mathrm{n}} \mathrm{x}_{\mathrm{i}} * \mathrm{~W}_{\mathrm{i}}$

where: $x_{i}$ is the mean diameter of the $i^{\text {th }}$ fraction, which corresponds to the average point between the sieve mesh in which the sample had been retained and the one immediately above, $\mathrm{W}_{\mathrm{i}}$ is the proportion of the total sample retained in that sieve.

Undisturbed soil samples ( $\mathrm{n}=54$; nine sites $\times$ six water potentials in NA, and $\mathrm{n}=54$ in PA) were collected with cores $(5 \mathrm{~cm}$ height $\times 5 \mathrm{~cm}$ diameter $)$ in the soil surface horizon $(3-8 \mathrm{~cm})$. Samples were saturated by gradually increasing the level of water in a tray, weighed to obtain the water content at saturation, and then equilibrated to the following matric potentials $(\psi):-0.004$ and $-0.01 \mathrm{MPa}$ on a tension table and $-0.03,-0.1,-0.5$, and -1.5 $\mathrm{MPa}$ in a Richard's pressure chamber (Klute, 1986). After equilibration, samples were weighed and soil resistance $(\mathrm{PR})$ was measured at a constant rate $\left(1.0 \mathrm{~cm} \mathrm{~min}^{-1}\right)$ using an electronic penetrometer with a cone of $4 \mathrm{~mm}$ basal diameter and angle of $60^{\circ}$. Readings obtained between 1 and $4 \mathrm{~cm}$ depth were averaged to obtain a single PR value. Next, samples were oven-dried at $105^{\circ} \mathrm{C}$ to determine the gravimetric water content and the soil bulk density (Bd) (Blake and Hartge, 1986). Then, the volumetric water content was calculated to elaborate the water release curve (WRC, $\theta=\mathrm{f} \psi$ ) for NA and PA.

Effective stress was estimated as the product between relative saturation and matric potential (from 0 to -100 $\mathrm{kPa}$ ) in absolute value, using the equation for unsaturated soils (Mullins and Panayiotopoulos, 1984):

$\sigma=\theta_{\mathrm{RS}^{*}}|\psi|$

where: $\sigma$ is effective stress $(\mathrm{kPa}) ; \theta_{\mathrm{RS}}$ is relative saturation (ratio between soil volumetric water content at the applied potential and soil water content at saturation; $\left.\theta_{\mathrm{RS}}=\theta / \theta_{)}\right) ;|\psi|$ is the absolute value of soil matric potential $(\mathrm{kPa})$.

The ratio between effective stress and PR was established adjusting the following linear model (equation 3):

$\mathrm{PR}=\mathrm{a}+\mathrm{b}_{\%} \sigma$

where: $\mathrm{a}$ and $\mathrm{b}$ are the model parameters.

Data of WRC were adjusted to the model proposed by van Genuchten (1980) (equation 4):

$\theta=\theta_{\mathrm{r}}+\left(\theta_{\mathrm{s}}-\theta_{\mathrm{r}}\right) /\left[1+(\alpha \psi)^{\mathrm{n}}\right]^{1 / \mathrm{n}}$

where: $\theta \mathrm{r}=$ residual water content $\left(\mathrm{cm}^{3} \mathrm{~cm}^{-3}\right), \theta \mathrm{s}=$ water content at saturation $\left(\mathrm{cm}^{3} \mathrm{~cm}^{-3}\right)$, and $\alpha, \mathrm{n}$ are fitting parameters.

The functional relationship between PR, $\theta$ and $\mathrm{Bd}$ was obtained adjusting data to the non linear model suggested by Busscher (1990) (equation 5): 
$\mathrm{PR}=\mathrm{a} * \theta^{\mathrm{b}} * \mathrm{Bd}{ }^{\mathrm{c}}$

where: $a, b, c$ are fitting parameters. The LLWR was calculated according to Silva et al. (1994) for each Bd. Water contents corresponding to field capacity $\left(\theta_{\mathrm{FC}}\right)$ and permanent wilting point $\left(\theta_{\mathrm{PWP}}\right)$ were obtained from equation (4) for $\psi=-0.01 \mathrm{MPa}$ and $\psi=-1.5 \mathrm{MPa}$, respectively. Equation (5) was used to determine the soil water content $\left(\theta_{\mathrm{PR}}\right)$ at which $\mathrm{PR}=3.5 \mathrm{MPa}$. This $\mathrm{PR}$ value is considered restrictive for alfalfa normal root growth (Materechera et al., 1991). Soil water content $\left(\theta_{\mathrm{AFP}}\right)$ at which air-filled porosity is $15 \%$, a value considered adequate for sensitive crops like alfalfa (Kay et al., 2006), was determined by equation 6 :

$\theta_{\mathrm{AFP}}=[(1-\mathrm{Bd} / \mathrm{Pd})-0.15]$

where: $\mathrm{Pd}=$ soil particle density $\left(\mathrm{Mg} \mathrm{m}^{-3}\right)$.

Soil particle density was measured with a picnometer of helium. The Pd value was equal to $2.58 \mathrm{Mg} \mathrm{m}^{-3}$.

Descriptive statistics and variance analyses of chemical data $(\mathrm{pH}$, organic matter, macronutrients, micronutrients) were carried out using SAS Institute (1991). Parameter comparison of equation 3 for $\mathrm{NA}$ and $\mathrm{PA}$ was made by applying the t test according to Steel and Torrie (1997). Adjustment of data related to soil resistance, water retention and LLWR was performed with non linear regression using the program developed by Leão et al. (2004) and SAS Institute (1991).

\section{Results and Discussion}

Mean values of $\mathrm{pH}$, organic matter $(\mathrm{OM})$, macro- and micronutrients for normal (NA) and patches (PA) areas (Tables 1 and 2) did not indicate differences for the soil chemical properties between the two areas. Besides, all values are within the nutrient sufficiency range. Moreover, some of them ( $\mathrm{Mn}, \mathrm{Cu}, \mathrm{Zn}, \mathrm{Fe}$ ) show high values, without reaching toxic levels (Diaz Zorita and Gambaudo, 2007). Thus, differences in soil chemical fertility can not be considered the reason for alfalfa lower productivity in patches.

Mean values and coefficients of variation $(\mathrm{CV})$ of $\mathrm{Bd}$ were $1.30 \mathrm{Mg} \mathrm{m}^{-3}$ and $6 \%$ for $\mathrm{NA}$, and $1.32 \mathrm{Mg} \mathrm{m}^{-3}$ and $4 \%$ for PA, indicating that the soil in patches is less heterogeneous. Average PR is lightly higher in PA (2.7 $\mathrm{MPa})$ than in $\mathrm{NA}(2.5 \mathrm{MPa})$. The high $\mathrm{CV}$ values $(\mathrm{PA}=$ $69 \%, \mathrm{NA}=61 \%)$ are due to the soil moisture gradient imposed on samples to obtain PR curves. The geometric mean diameter (GMD) values were 7.6 and $6.6 \mathrm{~mm}$ for NA and PA, respectively, showing differences $(\mathrm{F}=$ $7.51 ; p<0.01)$. Nonetheless, both values are within the range of size $(2-10 \mathrm{~mm})$ considered adequate for ion movement and mechanically not limiting for root growth (Braunack and Dexter, 1989b; Tisdall and Oades, 1982). However, the adequate aggregate size depends on texture, soil water content and the capacity of the species to undergo critical conditions (Braunack and Dexter 1989a; Braunack and Dexter, 1989b).

Table 1 - Descriptive statistics for chemical attributes of an Aquic Argiudoll in Central region of Santa Fe Province (Argentina), for two depths.

\begin{tabular}{|c|c|c|c|c|c|c|c|}
\hline Attribute & Global Mean & $\mathrm{SD}$ & $\mathrm{CV}$ & Min & Max & NA Mean & PA Mean \\
\hline \multicolumn{8}{|c|}{ Depth: 0-10 cm } \\
\hline $\mathrm{pH} \mathrm{CaCl}$ & 5.8 & 0.1 & 1.5 & 5.7 & 5.9 & $5.8 \mathrm{a}$ & $5.7 \mathrm{a}$ \\
\hline O.M. $\left(\mathrm{g} \mathrm{dm}^{-3}\right)$ & 28.5 & 4.3 & 15.1 & 22.3 & 32.6 & $27.8 \mathrm{a}$ & $29.1 \mathrm{a}$ \\
\hline $\mathrm{P}\left(\mathrm{mg} \mathrm{dm} \mathrm{m}^{-3}\right)$ & 52.4 & 14.3 & 27.3 & 31.2 & 69.3 & $59.2 \mathrm{a}$ & $45.7 \mathrm{a}$ \\
\hline $\mathrm{S}\left(\mathrm{mg} \mathrm{dm^{-3 } )}\right.$ & 10.9 & 0.9 & 8.3 & 9.7 & 12.2 & $10.6 \mathrm{a}$ & $11.2 \mathrm{a}$ \\
\hline $\mathrm{K}\left(\mathrm{mmol}_{\mathrm{c}} \mathrm{dm}^{-3}\right)$ & 12 & 1.2 & 9.9 & 9.9 & 13.2 & $12.6 \mathrm{a}$ & $11.7 \mathrm{a}$ \\
\hline $\mathrm{Ca}\left(\mathrm{mmol}_{\mathrm{c}} \mathrm{dm}^{-3}\right)$ & 67 & 7 & 10.4 & 57 & 74 & 69 a & $65 \mathrm{a}$ \\
\hline $\mathrm{Mg}\left(\mathrm{mmol}_{\mathrm{c}} \mathrm{dm}^{-3}\right)$ & 23.3 & 6.2 & 26.7 & 17 & 34 & $27.7 a$ & $19 \mathrm{a}$ \\
\hline $\mathrm{H}+\mathrm{Al}\left(\mathrm{mmol}_{\mathrm{c}} \mathrm{dm}^{-3}\right)$ & 24.8 & 2.6 & 10.6 & 22 & 29 & $24.3 \mathrm{a}$ & $25.3 \mathrm{a}$ \\
\hline $\mathrm{Al}\left(\mathrm{mmol}_{\mathrm{c}} \mathrm{dm}^{-3}\right)$ & 1.00 & 0.15 & 15.49 & 0.9 & 1.30 & $1.07 \mathrm{a}$ & $0.93 \mathrm{a}$ \\
\hline \multicolumn{8}{|c|}{ Depth: $10-20 \mathrm{~cm}$} \\
\hline $\mathrm{pH} \mathrm{CaCl} 2$ & 5.6 & 0 & 0.5 & 5.6 & 5.7 & $5.6 \mathrm{a}$ & $5.7 \mathrm{a}$ \\
\hline O.M. $\left(\mathrm{g} \mathrm{dm}^{-3}\right)$ & 30.9 & 4.1 & 13.4 & 25.1 & 37.2 & $27.9 \mathrm{a}$ & $33.8 \mathrm{a}$ \\
\hline $\mathrm{P}\left(\mathrm{mg} \mathrm{dm}{ }^{-3}\right)$ & 28.1 & 10.7 & 38 & 14.7 & 43.8 & $25.1 \mathrm{a}$ & $31 \mathrm{a}$ \\
\hline $\mathrm{S}\left(\mathrm{mg} \mathrm{dm^{-3 } )}\right.$ & 15.1 & 7.7 & 51.1 & 8.8 & 29.9 & $13.9 \mathrm{a}$ & $16.2 \mathrm{a}$ \\
\hline $\mathrm{K}\left(\mathrm{mmol}_{\mathrm{c}} \mathrm{dm}^{-3}\right)$ & 10.8 & 1 & 9.1 & 9.6 & 12.4 & $11.1 \mathrm{a}$ & $10.4 \mathrm{a}$ \\
\hline $\mathrm{Ca}\left(\mathrm{mmol}_{\mathrm{c}} \mathrm{dm}^{-3}\right)$ & 63.7 & 3.9 & 6.2 & 56 & 67 & $65 a$ & $62.3 \mathrm{a}$ \\
\hline $\mathrm{Mg}\left(\mathrm{mmol}_{\mathrm{c}} \mathrm{dm}^{-3}\right)$ & 19.2 & 2.1 & 11.2 & 17 & 22 & $20 \mathrm{a}$ & $18.3 \mathrm{a}$ \\
\hline
\end{tabular}

$\mathrm{SD}=$ Standard deviation $; \mathrm{CV}=$ Coefficient of variation; $\mathrm{Min}=$ Minimum; $\mathrm{Max}=$ Maximum; O.M. $=$ Soil organic matter $; \mathrm{P}=\mathrm{Phosphorus}$; $\mathrm{S}=$ Sulphur; $\mathrm{K}=$ Potassium; $\mathrm{Ca}=$ Calcium; $\mathrm{Mg}=$ Magnesium; $\mathrm{H}=$ Hydrogen; $\mathrm{Al}=$ Aluminum; $\mathrm{NA}=$ Normal area; $\mathrm{PA}=$ Patches. Within a given soil property same letters are not different $(p>0.05), \mathrm{n}=6$. 
Table 2 - Descriptive statistic for soil micronutrients of an Aquic Argiudoll in Central region of Santa Fe Province (Argentina), for two depths.

\begin{tabular}{|c|c|c|c|c|c|c|c|}
\hline Attribute & Global Mean & $\mathrm{SD}$ & $\mathrm{CV}$ & Min & Max & NA Mean & PA Mean \\
\hline \multicolumn{8}{|c|}{ Depth: $0-10 \mathrm{~cm}$} \\
\hline Boron $\left(\mathrm{mg} \mathrm{dm}^{-3}\right)$ & 0.70 & 0.14 & 18.18 & 0.60 & 0.96 & $0.71 \mathrm{a}$ & $0.78 \mathrm{a}$ \\
\hline Copper $\left(\mathrm{mg} \mathrm{dm}^{-3}\right)$ & 2.16 & 0.24 & 10.90 & 1.84 & 2.46 & $2.31 \mathrm{a}$ & $2.01 \mathrm{a}$ \\
\hline Zinc $\left(\mathrm{mg} \mathrm{dm}^{-3}\right)$ & 3.98 & 1.08 & 27.08 & 2.62 & 5.08 & $3.37 \mathrm{a}$ & $4.59 \mathrm{a}$ \\
\hline $\operatorname{Mn}\left(\mathrm{mg} \mathrm{dm}^{-3}\right)$ & 148.80 & 25.23 & 16.95 & 115.00 & 175.00 & $133.03 \mathrm{a}$ & $164.57 \mathrm{a}$ \\
\hline Iron $\left(\mathrm{mg} \mathrm{dm}^{-3}\right)$ & 60.31 & 11.20 & 18.57 & 47.24 & 76.22 & $63.00 \mathrm{a}$ & $57.63 \mathrm{a}$ \\
\hline \multicolumn{8}{|c|}{ Depth: $10-20 \mathrm{~cm}$} \\
\hline Boron $\left(\mathrm{mg} \mathrm{dm} \mathrm{dm}^{-3}\right)$ & 0.60 & 0.07 & 11.83 & 0.50 & 0.69 & $0.59 \mathrm{a}$ & $0.61 \mathrm{a}$ \\
\hline Copper $\left(\mathrm{mg} \mathrm{dm}^{-3}\right)$ & 1.85 & 0.09 & 4.62 & 1.76 & 1.96 & $1.88 \mathrm{a}$ & $1.82 \mathrm{a}$ \\
\hline Zinc $\left(\mathrm{mg} \mathrm{dm}^{-3}\right)$ & 3.56 & 0.98 & 27.61 & 2.14 & 4.70 & $3.49 \mathrm{a}$ & $3.63 \mathrm{a}$ \\
\hline $\operatorname{Mn}\left(\mathrm{mg} \mathrm{dm}^{-3}\right)$ & 149.47 & 17.92 & 11.99 & 131.80 & 175.20 & $143.83 \mathrm{a}$ & $155.10 \mathrm{a}$ \\
\hline Iron $\left(\mathrm{mg} \mathrm{dm}^{-3}\right)$ & 50.82 & 9.54 & 18.78 & 37.92 & 64.06 & $49.47 \mathrm{a}$ & $52.18 \mathrm{a}$ \\
\hline
\end{tabular}

$\mathrm{SD}=$ Standard deviation; $\mathrm{CV}=$ Coefficient of variation; $\mathrm{Min}=$ Minimum; $\mathrm{Max}=$ Maximum; $\mathrm{Mn}=$ Manganese. NA $=$ Normal area; $\mathrm{PA}=$ Patches. Within a given soil property same letters are not $\mathrm{t}$ different $(p>0.05), \mathrm{n}=6$.

Soil aggregate size distribution indicated little difference between areas. Nevertheless, a difference was found $(\mathrm{F}=7.38 ; p<0.01)$ for the fraction smaller than $1 \mathrm{~mm}$, proportionally larger in PA than in NA. Predominance of small aggregates has been associated to conditions of poor aeration, greater pore tortuosity and high mechanical resistance, factors that may limit crop development (Hoffmann and Jungk, 1995). As the proportion of small size aggregates and soil bulk density increase, particle contact also increases. Similarly, soil drying promotes particle contact as well as the formation of new connections among them and among soil micro-aggregates which, in turn, increase the water retention energy of the soil matrix. This process, known as effective stress, is responsible for increasing soil resistance to root penetration (Mullins and Panayiotopoulos, 1984).

Penetration resistance and effective stress relations are shown in Figure 1 for PA and NA. A positive and linear relation between both variables is verified in the 0 to $-100 \mathrm{kPa}$ matric potential range, within the measured range. Effective stress accounted for 83 and $60 \%$ of the total variability in PR for PA and NA, respectively. Several researchers have mentioned that effective stress is the main reason of high values of soil resistance to root penetration (Giarola et al., 2003; To and Kay, 2005; Whalley et al., 2005).

The "a" coefficient (Equation 3) did not differ between PA and NA $(t=1.441 ; p=0.153)$. This coefficient is related to soil particle cohesion, which is mainly produced by aggregating agents, such as organic substances, silicon and iron in its poor crystalline forms (Vepraskas, 1984). Both areas present similar texture and similar OM contents besides, being separated by very small distances. These conditions justify the lack of difference in the "a" coefficient. The "b" coefficient (Equation 3) was different in PA and NA $(t=3.331 ; p=0.001)$. The increase in soil mechanical resistance associated to

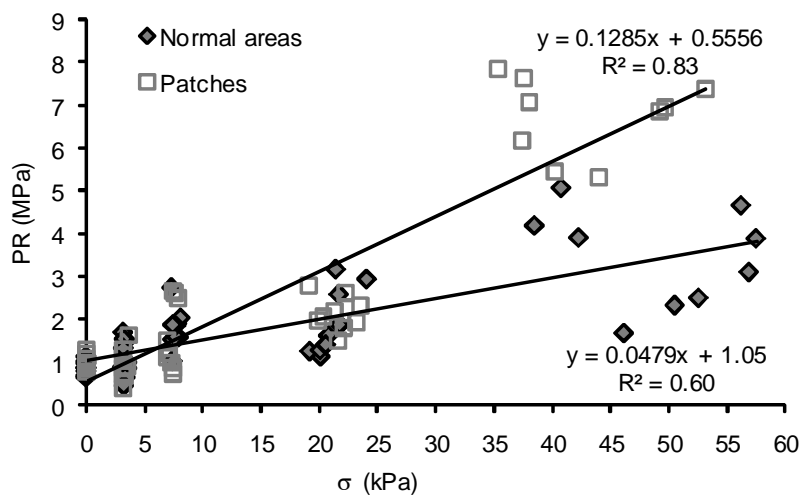

Figure 1 - Soil penetration resistance (PR) versus effective stress $(\sigma)$ in Normal areas and Patches of the alfalfa pasture.

the increase in effective stress was higher in PA. Patches are mainly located in depressed micro-reliefs. As a result, the soil receives water from rain and from surrounding areas (NA). This greater water flow may contribute to break down macro-aggregates into small aggregates and loose material as well as to rearrange fine particles, modifying pore size distribution. These conditions favor particle contact and the formation of small capillary pores, which determine that water menisci bind particles together strongly when soil is wet. On the other hand, when soil becomes dry, interparticle friction increases, increasing soil mechanical resistance (Vepraskas, 1984). Similar results were found by Vepraskas (1984) and Giarola et al. (2003).

High values of mechanical resistance in soils of the Rolling Pampas were also found by Alvarez et al. (2009). These high values were attributed to fine particle organization that results from soil hardening (Taboada et al., 1998a). This process becames more important in silty soils of the Argentinean Pampas because of the particular shape and origin of the silt particles, mainly 
phytoliths (Cosentino and Pecorari, 2002). Moreover, this material was associated to the structural instability of Argiudolls by Sasal et al. (2006) and Taboada et al. (2008).

The coefficients of the PR model (equation 5) for PA and NA (Table 3) were all statistically significant since the confidence interval does not include the $O$ (zero) value (Glantz and Slinker, 1990). PR was negatively affected by soil water content and positively by Bd, then corroborating to the assumption of equation 3 . In both cases, PR was less conditioned by the former than by the later, suggesting that soil compaction has more impact than soil drying in reaching critical values of soil resistance. $\mathrm{PR}$ behavior with respect to $\mathrm{Bd}$ and $\theta$ is in agreement with the findings of Leão et al. (2006), Silva et al. (1994); Tormena et al. (1999). The fitted model explained $85 \%$ and $90 \%$ of data for PA and NA, respectively. The value of water content in which $P R=3.5$ $\mathrm{MPa}$, calculated for the mean $\mathrm{Bd}$ value, is greater in PA $\left(0.26 \mathrm{~m}^{3} \mathrm{~m}^{-3}\right)$ than in NA $\left(0.24 \mathrm{~m}^{3} \mathrm{~m}^{-3}\right)$. This implies that in PA the soil must remain wetter for plant growth not to be affected by soil mechanical resistance.

Adjustment coefficients of the soil water release curve (equation 4) for patches and normal areas are presented in Table 4 . The model accounted for $99 \%$ of the data variability for both areas. $\theta_{\mathrm{FC}}$ value, calculated with the model corresponding to each area, is slightly higher in NA than in PA, probably due to differences in particle organization as suggested by the $\mathrm{b}$ coefficient of equation 3. $\theta_{\text {PWP }}$ values do not present differences between areas, which was expected since $\theta_{\text {PWP }}$ mainly depends on soil texture and both areas are of the same soil.

Soil water contents setting the LLWR limits for each measured Bd are shown in Figures 2 and 3 for NA and $\mathrm{PA}$, respectively. $\mathrm{Bd}$ increase is associated to an increase in $\theta_{\mathrm{PR}}$ and a decrease in $\theta_{\mathrm{AFP}}$ in both areas, but it did not affect the $\theta_{\mathrm{FC}}$ and $\theta_{\mathrm{PWP}}$ values. Similar results were found by Zou et al. (2001) for soils of similar particle size distribution. $\theta_{\mathrm{PR}}$ was the lower LLWR limit in both areas,

Table 3 - Fitted parameters for the soil penetration resistance curve model in Normal areas and Patches of a pasture of alfalfa. $P R=a^{*} \theta^{b} * B d c$

\begin{tabular}{cccc}
\hline Parameter & \multicolumn{1}{c}{ Value } & LL & UL \\
\hline \multicolumn{4}{c}{ Normal area (NA) } \\
a & 0.0399 & 0.017 & 0.0627 \\
b & -2.0627 & -2.3561 & -1.7693 \\
c & 5.8355 & 4.65 \\
\hline \multicolumn{4}{c}{ Patches (PA) } \\
a & 0.0484 & 0.016 \\
b & -1.9927 & -2.2448 & -1.7407 \\
c & 5.6132 & 3.9435 & 7.2828 \\
\hline
\end{tabular}

$\mathrm{PR}=$ Soil penetration resistance $(\mathrm{MPa}) ; \theta=$ Water content $\left(\mathrm{cm}^{3} \mathrm{~cm}^{-3}\right) ; \mathrm{Bd}=$ Bulk density $\left(\mathrm{Mg} \mathrm{m}^{-3}\right) ; \mathrm{a}, \mathrm{b}$, and $\mathrm{c}$ are parameters of model. LL, UL = Lower and upper limit of the confidence interval of $95 \%$. NA: $\mathrm{F}=250.26 ; \operatorname{Pr}>\mathrm{F}<0.0001 ; \mathrm{R}^{2}=0.85$; PA: $\mathrm{F}=363.89 ; \operatorname{Pr}>\mathrm{F}<0.0001 ; \mathrm{R}^{2}=0.90 ; \mathrm{n}=54$. indicating that alfalfa growth will be affected by the high soil resistance before soil water content reaches the permanent wilting point. Nonetheless, the PR effect is more severe in PA, which is denoted by the large slope of the straight line. Stirzaker et al. (1986) indicated that in hard soils, water and nutrient absorption can become limiting due to the root difficulty to penetrate the soil, despite the fact of having adequate chemical fertility.

For PA, $\theta_{\mathrm{AFP}}$ replaces $\theta_{\mathrm{FC}}$ as the upper limit of the LLWR at Bd $\geq 1.26 \mathrm{Mg} \mathrm{m}^{-3}$, which corresponds to $93 \%$ of all cases. For NA, aeration was the upper LLWR limit in $89 \%$ of all cases. Consequently, inadequate aeration will firstly affect root growth in PA. Oxygen deficiency originates severe damage to alfalfa predisposing plants to root infections by Phytophthora (Phytophthora

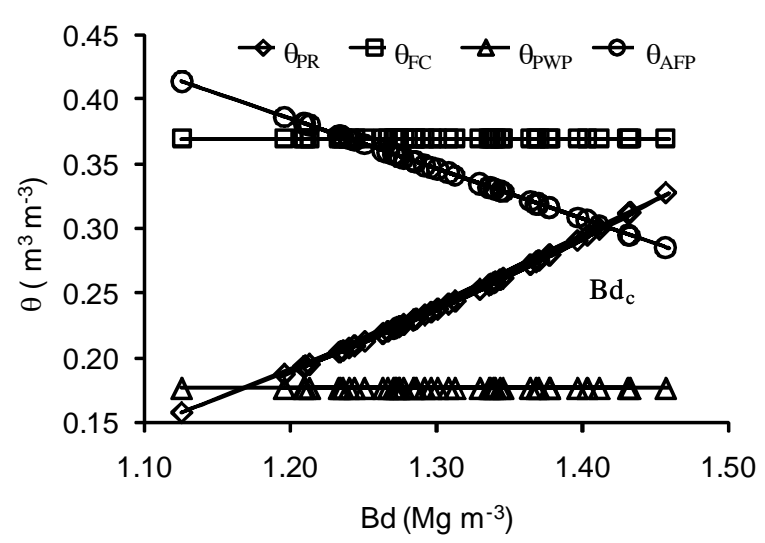

Figure 2 - Soil water content $(\theta)$ variation with soil bulk density $(\mathrm{Bd})$ at the critical limits of field capacity $\left(\theta_{\mathrm{FC}}=-0.01\right.$ $\mathrm{MPa})$, permanet wilting point $\left(\theta_{\mathrm{PWP}}=-1.5 \mathrm{MPa}\right)$, air filled porosity of $15 \%\left(\theta_{\mathrm{AFP}}\right)$ and soil penetration resistance $\left(\theta_{\mathrm{PR}}\right.$ of $\left.3.5 \mathrm{MPa}\right)$ in Normal areas of a pasture of alfalfa $L L W R=$ least limiting water range. $\mathrm{Bd}_{\mathrm{c}}=$ critical soil bulk density (LLWR $=0$ ).

Table 4 - Fitted parameters for the water release curve model in Normal areas and Patches of a pasture of alfalfa. CRH: $\theta=\theta_{r}+\left(\theta_{s}-\theta_{r}\right) /\left[1+(\alpha \psi)^{n}\right]^{1 / n}$

\begin{tabular}{|c|c|c|c|}
\hline Parameter & Value & LL & UL \\
\hline \multicolumn{4}{|c|}{ Normal area (NA) } \\
\hline$\alpha$ & 0.6466 & 0.5207 & 0.7725 \\
\hline $\mathrm{n}$ & 1.1503 & 1.1442 & 1.1565 \\
\hline$\theta_{\mathrm{s}}$ & 0.50 & 0.4886 & 0.5024 \\
\hline \multicolumn{4}{|c|}{ Patches (PA) } \\
\hline$\alpha$ & 0.0484 & 0.016 & 0.0707 \\
\hline $\mathrm{n}$ & -1.9927 & -2.2448 & -1.7407 \\
\hline$\theta_{\mathrm{s}}$ & 5.6132 & 3.9435 & 7.2828 \\
\hline
\end{tabular}

$\theta=$ volumetric water content $\left(\mathrm{cm}^{3} \mathrm{~cm}^{-3}\right) ; \theta_{\mathrm{s}}=$ saturated volumetric water content $\left(\mathrm{cm}^{3} \mathrm{~cm}^{-3}\right) . \theta_{\mathrm{r}}=$ residual volumetric water content $\left(\mathrm{cm}^{3} \mathrm{~cm}^{-3}\right)$, it was assumed $=0 ; \psi=$ soil matric potencial $(\mathrm{kPa}) ; \alpha, \mathrm{n}=$ fitted parameter for the water release curve $(\mathrm{CRH}) . \mathrm{LL}, \mathrm{UL}=$ Lower and upper limit of the confidence interval of $95 \%$. NA: $F=24649.9 ; \operatorname{Pr}>F<0.0001 ; R^{2}=0.99$; PA: $\mathrm{F}=25905.4 ; \operatorname{Pr}>\mathrm{F}<0.0001 ; \mathrm{R}^{2}=0.99 ; \mathrm{n}=54$. 


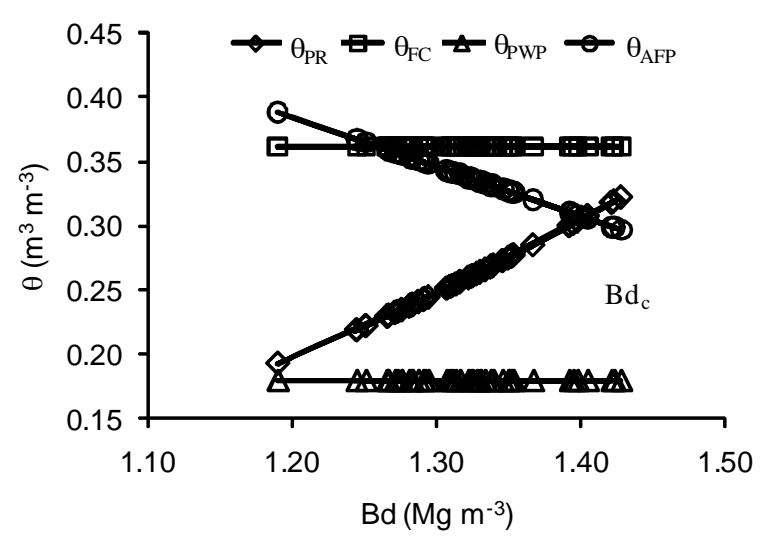

Figure 3 - Soil water content $(\theta)$ variation with soil bulk density $(\mathrm{Bd})$ at the critical limits of field capacity $\left(\theta_{\mathrm{FC}}=-0.01\right.$ $\mathrm{MPa})$, permanet wilting point $\left(\theta_{\mathrm{PWP}}=-1.5 \mathrm{MPa}\right)$, air filled porosity of $15 \%\left(\theta_{\mathrm{AFP}}\right)$ and soil penetration resistance of $3.5 \mathrm{MPa}\left(\theta_{\mathrm{PR}}\right)$ in the patches of a pasture of alfalfa $\mathrm{LLWR}=$ least limiting water range. $\mathrm{Bd}_{\mathrm{c}}=$ critical soil bulk density $(L L W R=0)$

megasperma f. sp. medicaginis) and delaying stem growth, apart from inducing premature senescence of leaves, nutrient deficiency, and slowing down root growth (Zook et al., 1986).

The maximum amplitude of the LLWR was $0.168 \mathrm{~m}^{3}$ $\mathrm{m}^{-3}$ and $0.194 \mathrm{~m}^{3} \mathrm{~m}^{-3}$, in PA and NA, respectively. The small amplitude in PA suggests a more limiting soil environment for root growth. Besides, it implies in a greater probability for plants to suffer stress during their growth cycle, especially in productive systems without irrigation (Silva and Kay, 1997). Critical soil bulk densities $\left(\mathrm{Bd}_{\mathrm{c}}\right)$, i.e. $\mathrm{Bd}$ in which the $\mathrm{LLWR}=0$, were 1.40 and $1.42 \mathrm{Mg} \mathrm{m}^{-3}$ for PA and NA. Bd values equal or greater than $\mathrm{Bd}_{\mathrm{c}}$ indicate severe structural degradation of the soil (Leão et al., 2006). Its impact in biomass production is difficult to be predicted since plant growth is a dynamic process and different morphological and physiological adaptations take place when the environment becomes stressful. Nevertheless, authors agree that crop productivity is reduced (Benjamin et al., 2003; Masle, 1998; Silva and Kay, 1997; Silva et al., 2004; Wheaton et al., 2008). The smaller value of $\mathrm{Bd}_{\mathrm{c}}$ in PA indicates that plants will grow under unsuitable conditions at a lower state of soil compaction.

Overall results indicate that the soil physical quality in patches is lower than that of "normal" areas. Inadequate oxygen supply during periods of excessive soil moisture, and inappropriate soil mechanical resistance on periods of water deficit will exert a greater negative impact on alfalfa growth in PA than in NA. Alfalfa is currently grazed when plants are at the adequate phenological state in the normal areas since they occupy a greater surface in the field. As a consequence, plants in the patches are grazed before they reach the adequate moment. This fact does not allow them to accumulate enough amounts of reserves in their crown to endure subsequent regrowths. In this way, the intensive grazing system and the characteristics of alfalfa growth may contribute to magnify the impact of soil properties that act as limiting factors, inducing anticipated plant death in patches.

\section{Conclusions}

There are only differences in soil physical properties between normal areas and those considered patches. The soil from micro-relief with patches has an inferior physical quality, which imposes stressful conditions to plant growth. These conditions associated to the particular alfalfa characteristics and those of the grazing system would be responsible for the lower productivity and longevity of the crop in patches.

\section{References}

Alvarez, C.; Taboada, MA.; Gutierrez Boem, F.; Bono, A.; Fernandez, P.; Prystupa, P. 2009. Topsoil properties as affected by tillage systems in the rolling Pampa region of Argentina. Soil Science Society of America Journal 73: 1242-1250.

Benjamin, J.G.; Nielsen, D.C.; Vigil, M.F. 2003. Quantifying effects of soil conditions on plant growth and crop production. Geoderma 116: 137-148.

Blake, G.R.; Hartge, K.H. 1986. Bulk density. p. 363-375. In: Klute, A., ed. Methods of soil analysis: physical and mineralogical methods. 2ed. American Society of Agronomy, Madison, WI, USA.

Bonadeo, E.; Hampp, E.R.; Bongiovanni, M.D.; Moreno, I.S.; Odorizzi. A. 2006. Relationships between soil physical and chemical properties and alfalfa (Medicago sativa L.) roots in patched soils. Ciencia del Suelo 24: 101-107. (In Spanish with abstract in English).

Braunack, M.V.; Dexter, A.R. 1989a. Soil aggregation in the seedbed: a review. I. Properties of aggregates and beds of aggregates. Soil and Tillage Research 14: 259-279.

Braunack, M.V.; Dexter, A.R. 1989b. Soil aggregation in the seedbed: a review. II. Effect of aggregate sizes on plant growth. Soil and Tillage Research 14: 281-298.

Busscher, W.J. 1990. Adjustment of flat-tipped penetrometer resistance data to a common water content. Transaction of the ASAE 33: 519-524.

Comeron, E.; Romero, L. 2007. Use of the alfalfa by milk cows during grazing. p. 303-331. In: Basigalup, D.H., ed. The alfalfa crop in Argentina. Ediciones INTA. Buenos Aires, Argentina. (in Spanish).

Cosentino, D.J.; Pecorari, C. 2002. Impact of low-density minerals on soil physical properties of soils of the Pampean region. Ciencia del Suelo 20: 9-16. (in Spanish with abstract in English).

Diaz-Zorita, M.; Gambaudo, S. 2007. Fertilization and liming in alfalfa. p. 227-246. In: Basigalup, D.H., ed. The alfalfa crop in Argentina. Ediciones INTA, Buenos Aires, Argentina. (in Spanish).

Giarola, N.F.B.; Silva, A.P., Imhoff, S.; Dexter, A.R. 2003. Contribution of natural soil compaction on hardsetting behavior. Geoderma 113: 95-108.

Glantz, S.A.; Slinker, B.K. 1990. Primer of Applier Regression and Analysis of Variance. McGraw-Hill, New York, NY, USA.

Hamza, MA.; Anderson, W.K. 2005. Soil compaction in cropping systems: a review of the nature, causes and possible solutions. Soil and Tillage Research 82: 121-145.

Harrison, D.F.; Cameron, K.C.; McLaren, R.G. 1994. Effects of subsoil loosening on soil physical properties, plant root growth, and pasture yield. New Zealand Journal of Agricultural Research 37: 559-567. 
Hoffmann, C.; Jungk, A. 1995. Growth and phosphorus supply of sugar beet as affected by soil compaction and water tension. Plant and Soil 176: 15-25.

Juan, N.; Romero, L.; Bruno, O. 1995. Conservation of the alfalfa grass. p. 173-192. In: Hijano, E.H.; NAVARRO, A., eds. The alfalfa in Argentina. Editar, San Juan, Argentina. (in Spanish).

Kay, B.D.; Hajabbasi, M.A.; Ying, J.; Tollenaar, M. 2006. Optimun versus non-limiting water contents for root growth, biomasa accumulation, gas exchange and the rate of development of maiz (Zea mays L.). Soil and Tillage Research 88: 42-54.

Klute, A. 1986. Water retention: Laboratory Methods. chap. 26. p. 635-660. In: Klute, A., ed. Methods of soil analysis-physical and mineralogical methods. American Society of Agronomy. Madison, WI, USA.

Leão, T.P.; Silva, A.P.; Perfect, E.; Tormena C. 2005. A simplified Excel algoritm for estimating the least limiting water range for soil. Agronomy Journal 97: 1210-1215.

Leão, T.P.; Silva, A.P.; Macedo, M.C.M.; Imhoff, S.; Euclides, V.P.B. 2006. Least limiting water range: a potential indicator of changes in near-surface soil physical quality after the conversion of Brazilian Savanna into pasture. Soil and Tillage Research 88: 279-285.

Mapfumo, E.; Chanasyk, D.S.; Naeth, M.A.; Baron V.S. 1998. Forage growth and yield components as influenced by subsurface compaction. Agronomy Journal 90: 805-812.

Masle, J. 1998. Growth and stomatal responses of wheat seedlings to spatial and temporal variations in soil strength of bi-layered soils. Journal of Experimental Botany 49: 1245-1257.

Masle, J.; Passioura, J.B. 1987. The effect of soil strength on the growth of young wheat plants. Australian Journal of Plant Physiology 14: 643-656.

Materechera, S.A.; Dexter, A.R.; Alston, A.M. 1991. Penetration of very strong soils by seedling roots of different plant species. Plant and Soil 135: 31-41.

Mosconi, F.; Priano, L.; Moscatelli, G.; Salazar, J.L.; Gutierrez, T.; Caceres, L. 1981. Soil map of the province of Santa Fe. INTA-MAG, Santa Fe, Argentina. 246 p. (in Spanish)

Mullins, C.E., Panayiotopoulos, K.P. 1984. The strength of unsatured mixture of sand and kaolin and the concept of effective stress. Journal of Soil Science 35: 459-468.

Panigatti, J.L.; Piñeiro, A.; Mosconi, F.P. 1971. Patches in crops of the Central zone of Santa Fe. Revista de Investigaciones Agropecuarias 8: 141-154. (in Spanish).

Passioura, J.B. 1988. Root signals control leaf expansion in wheat seedlings growing in drying soil. Australian Journal of Plant Physiology 15: 687-693.

Perfect, E.; Díaz-Zorita, M.; Grove, J.H. 2002. A prefractal model for predicting soil fragment mass-size distributions. Soil and Tillage Research 64: 79-90.

Romero, L.A.; Giorgi R.E.; Tosolini, R.A.; Sapino, V.I.; Giailevra, D.C.; Zapatero, D.A.; Comerón, E.A. 2000. Losses in alfalfa pastures associated with water flooding. Revista Argentina de Producción Animal 20: 221-222. (in Spanish).

SAS Institute. 1991. SAS/STAT Procedure Guide for Personal Computers. 5ed. SAS Institute, Cary, NC, USA.

Sasal, M.C.; Andriulo, A.E.; Taboada, M.A. 2006. Soil porosity characteristics and water movement under zero tillage in silty soils in Argentinean Pampas. Soil and Tillage Research 87: 9-18.

Silva, A.P.; Imhoff, S.; Kay, B.D. 2004. Plant response to mechanical resistance and air-filled porosity of soils under conventional and no-tillage. Scientia Agricola 61: 451-456.

Silva, A.P; Kay, B.D. 1997. Effect of soil content variation on the least limiting water range. Soil Science Society of America Journal 61: 884-888.
Silva, A.P.; Kay, B.D.; Perfect, E. 1994. Characterization of the least limiting water range of soils. Soil Science Society of America Journal 58: 1775-1781.

Steel, R.G.D; Torrie, J.H. 1997. Biostatistic: Principles and Procedures. McGraw-Hill, México City, México. (in Spanish).

Stirzaker, R.J.; Passioura, J.B.; Wilms, Y. 1996. Soil structure and plant growth: impact of bulk density and biopores. Plant and Soil 185: 151-162.

Taboada, M.A.; Barbosa, O.A.; Cosentino, D.J. 2008. Null creation of air filled structural pores by soil cracking and shrinkage in silty loam soils. Soil Science 173: 130-142.

Taboada, M.A.; Lavado, R.S.; Svartz, H.; Segat, A.M.I. 1999. Structural stability changes in a grazed grassland Natraquoll of the flooding Pampa, Argentina. Wetlands 19: 50-55.

Taboada, M.A.; Micucci, F.G.; Cosentino, D.J.; Lavado, R.S. 1998a. Comparison of compaction induced by conventional and zero tillage in two soils of the Rolling Pampa of Argentina. Soil and Tillage Research 49: 57-63.

Taboada, M.A.; Rubio, G.; Lavado, R.S. 1998b. The deterioration of tall wheatgrass pastures in saline sodic soils. Journal of Range Management 51: 241-246.

Tisdall, J.M.; Oades, J.M. 1982. Organic matter and water-stable aggregates in soils. Journal of Soil Science 33: 141-163.

To, J.; Kay, B.D. 2005. Variation in penetrometer resistance with soil properties: the contribution of effective stress and implications for pedotransfer. Geoderma 126: 261-276.

Tormena, C.A.; Silva, A.P.; Libardi, P.L. 1999. Soil physical quality of a Brazilian Oxisol under two tillage systems using the least limiting water range. Soil and Tillage Research 52: 223-232.

Van Genuchten, M.T. 1980. A closed-form equation for predicting the hydraulic conductivity of unsaturated soils. Soil Science of America Journal 44: 892-898.

Van Raij, B. 1998. Bioavailable test: alternatives to standard soil extractions. Communications in Soil Science and Plant Analysis 29: 1553-1570.

Veen, B.W.; Boone, F.R. 1990. The influence of mechanical resistance and soil water on the growth of seminal roots of maize. Soil and Tillage Research 16: 219-226.

Vepraskas, M.J. 1984. Cone index of loamy sands as influenced by pore size distribution and effective stress. Soil Science Society of America Journal 48: 1220-1225.

Whalley, W.R.; Leeds-Harrison, P.B.; Clark, L.J.; Gowing, D.J.G. 2005. Use of effective stress to predict the penetrometer resistance of unsaturated agricultural soils. Soil and Tillage Research 84: 18-27.

Wheaton, A.D; McKenzie, B.M.; Tisdall, J.M. 2008. Management to increase the depth soft soil improves soil conditions grapevine performance in an irrigated vineyard. Soil and Tillage Research 98: 68-80.

White, W.M. 1993. Dry agrégate distribution. p. 659-662. In: Carter, M.R., ed. Soil sampling and methods of analysis. Lewis, Canada, CA.

Zook, D.M.; Erwin, D.C.; Stolzy, L.H. 1986. Anatomical, morphological, and physiological response of alfalfa to flooding. Plant and Soil 96: 293-296.

Zou, C.; Penfold, C; Sands, R.; Misra, R.K.; Hudson, I. 2001. Effects of soil air-filled porosity, soil matric potencial and soil strength on primary root growth of radiate pine seedlings. Plant and Soil 236: 105-115.

Received October 30, 2009

Accepted March 31, 2010 